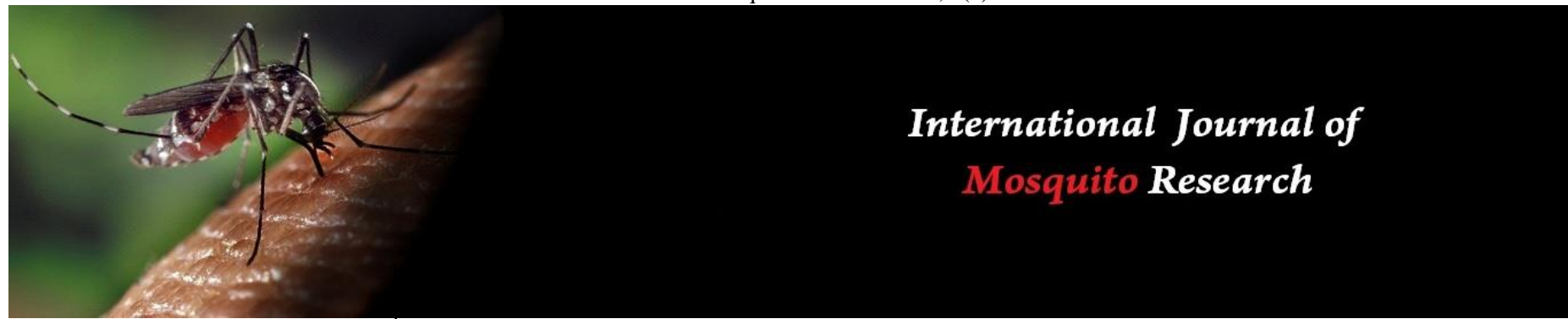

ISSN: 2348-5906

CODEN: IJMRK2

IJMR 2021; 8(2): 134-144

(C) 2021 IJMR

www.dipterajournal.com

Received: 17-01-2021

Accepted: 04-03-2021

Ranjana Rani

P.G. Department of Zoology,

DAV College, Sector-10,

Chandigarh, India

\section{Sandeep Kaur}

Department of Zoology, Panjab

University, Sector-14,

Chandigarh, India

\section{Sukhbir Kaur}

Department of Zoology, Panjab

University, Sector-14,

Chandigarh, India

Sagan Deep Kaur

P.G. Department of Zoology,

DAV College, Sector-10,

Chandigarh, India
Corresponding Author: Sagan Deep Kaur P.G. Department of Zoology, DAV College, Sector-10, Chandigarh, India

\section{Seasonal dynamics and relative abundance of seven Japanese encephalitis vectors of Culex sitiens group and their association with meteorological factors in various ecological habitats of Chandigarh and its surrounding areas}

\author{
Ranjana Rani, Sandeep Kaur, Sukhbir Kaur and Sagan Deep Kaur
}

DOI: https://doi.org/10.22271/23487941.2021.v8.i2b.527

\section{Abstract}

Japanese encephalitis (JE) is one of the most common cause of acute viral encephalitis which poses serious infection of the brain. Species under Culex sitiens group are major vectors responsible for the transmission of JE. The knowledge about the occurrence of Culex sitiens group in Chandigarh and its adjoining areas is very scanty. Hence, present investigations have been carried out to study seasonal dynamics and relative abundance of JE vectors in these areas. Detailed surveys have been carried out in various ecological habitats of Chandigarh from June 2017-November 2019. The monthly meteorological parameters of the study-area like temperature, rainfall, and relative humidity were compared and statistically correlated with JE vector density. As many as 34 mosquito species belonging to 8 genera have been recorded. Genus Culex contributed maximum (69.40\%) of the total catch which included 7 incriminated JE species from the studied habitats. These vectors showed highest density in monsoon and post-monsoon periods. The abundance of Culex sitiens vectors indicates their importance for evaluation of the seasonal dynamics which ultimately demarcates the risk of JE outbreak. The observation over a period of three years is highly significant to assess the seasonal dynamicity of JE vector population in different seasons and its abundance in different ecological habitats.

Keywords: Japanese encephalitis, Culex, sitiens group, vector, Chandigarh

\section{Introduction}

Japanese encephalitis (JE) is one of the most dreadful and emerging mosquito borne viral disease prevalent in India. About a century ago, the disease was endemic in East Asia, especially in Japan, China, Korea and Taiwan and spread widely in Southeast Asia subsequently causing outbreaks of varying magnitudes in India, Indonesia, Burma, Sri Lanka and Thailand ${ }^{[1]}$. It was less recognized in India untill 1973, confined only to southern parts of India with low prevalence. Since then, various outbreaks have been observed in other states like Bihar, Uttar Pradesh, Assam, Manipur, Maharashtra, Haryana, West Bengal, Orissa and union territories of Goa and Pondicherry ${ }^{[2]}$. The incidence of JE in recent times is showing an increasing trend in the north-western states of India. Roop et al. (2013), reported the first indigenous transmission of JE in four urban areas of Delhi ${ }^{[3]}$. The Directorate of National Vector Borne Disease Control Programme (NVBDCP) reported 1214 cases and 181 deaths due to JE from 15 states/UTs in 2011. However, since 2014 to till date, NVBDCP reported 2560 cases and 297 deaths from Uttar Pradesh, 499 cases, 90 deaths from Bihar whereas, 13 cases with 2 deaths in Haryana, 3 cases from Punjab and 19 other states ${ }^{[4]}$. In 2018, two children have been found positive with JE virus in Solan district of Himachal Pradesh and one death of a child due to JE was also reported from Dera Bassi near Chandigarh in 2018 (Unpublished data). In India, so far Japanese encephalitis virus has been isolated from 10 species of genus Culex ${ }^{[4]}$.

These species prefer to breed in variety of ecological habitats such as stagnant water in paddy fields or drainage ditches, temporary freshwater habitat, polluted waters, small pools, water with filamentous algal growth ${ }^{[4]}$ and water body with high abundance of aquatic weeds like 
Eichhornia, Phragmites, Typha etc. (Mosquito Research and Management 2013). Change in the environment has a great impact on the breeding habitats of different species. The meteorological factors affect adult mosquito species by altering the quality and quantity of breeding habitats. The relationship between weather parameters and mosquito population can provide important information to determine vector abundance and risk associated with their increasing density.

Hence, it is worthwhile to mention here, that the disease is spreading at an alarming rate in almost every part of the country, including northwest India but, except for few references, the data on mosquito species, particularly of JE vectors prevailing in Chandigarh and its adjoining areas is not available. In the present communication, entomological surveys were conducted for the period of three years to find out the seasonal prevalence and relative abundance of mosquito species (known to be the vectors of Japanese encephalitis virus) from different ecological habitats of Chandigarh. Out of the collected nineteen species of genus Culex, seven species associated with JE have been recorded in this area. Therefore, keeping in view, the importance of mosquito species in carrying JE virus, the present investigations have been carried out to explore the association with weather parameters with JE vectors in various rural and urban ecological habitats in and around Chandigarh from premonsoon to post-monsoon periods.

\section{Material and Methods}

2.1 Study area: The study was conducted in different ecological habitats of Chandigarh. Chandigarh is located near foothills of the Shivalik range of Himalayas in northwest India $\left(30.74^{\circ} \mathrm{N}, 76.79^{\circ} \mathrm{E}\right)$ bordering Punjab and Haryana states. The study areas have variety of favourable habitats for mosquito breeding like thick vegetation which cover around $8.77 \%$ of total geographical areas, 3245.30 hectares forest area, green belts of gardens, lakes full of flora and fauna (also attracts various species of migratory birds from parts of Siberia and Japan in the early winter season), paddy fields and slum areas on its outskirts. This area also receive occasional rainfalls of $1103.7 \mathrm{~mm}$ annually, maximum in monsoons (80\%) followed by post-monsoons. Different seasons like (i) Summer occur in March-May, (ii) Pre-monsoon (June-July), (iii) Monsoon (August-September), (iv) Post-monsoon (October-November) and (v) Winter (December - Mid March).

2.2 Mosquito collection and Identification: Collection sites covering both urban and rural habitats were selected and more than 109 rounds of surveys were conducted for three years June 2017- November 2019 to catch mosquito samples. These sites were further categorized into four different ecological habitats viz; developed urban areas, garden belts, surrounding villages and slum areas (Fig. 1). The collection of adult mosquitoes was made with oral aspirator and hand-nets from various resting sites i.e. in and around cattle sheds, human dwellings, mixed dwellings and other sites in and around Chandigarh from 6am to $9 \mathrm{am}$ in the morning and 4 pmto $8 \mathrm{pm}$ in the evening hours.

These samples were then brought to the laboratory, killed at $30-37^{\circ} \mathrm{C}$ for $8-10$ minutes and preserved in insect storage boxes after pinning. The specimens were individually counted, examined and further identification was done under a Stereo Zoom Trinocular microscope for generic and species separation by following the standard identification keys [5, 6, 7, 8, 9]. The species were further confirmed by studying the details of their male and female genitalia. The slides of male and female genitalia were prepared by following the method of Siverly and Shroyer (1974) ${ }^{[10]}$ and examined at 20x and 40x magnification using compound microscope and photographed by using digital Gentx camera and Gryphax software

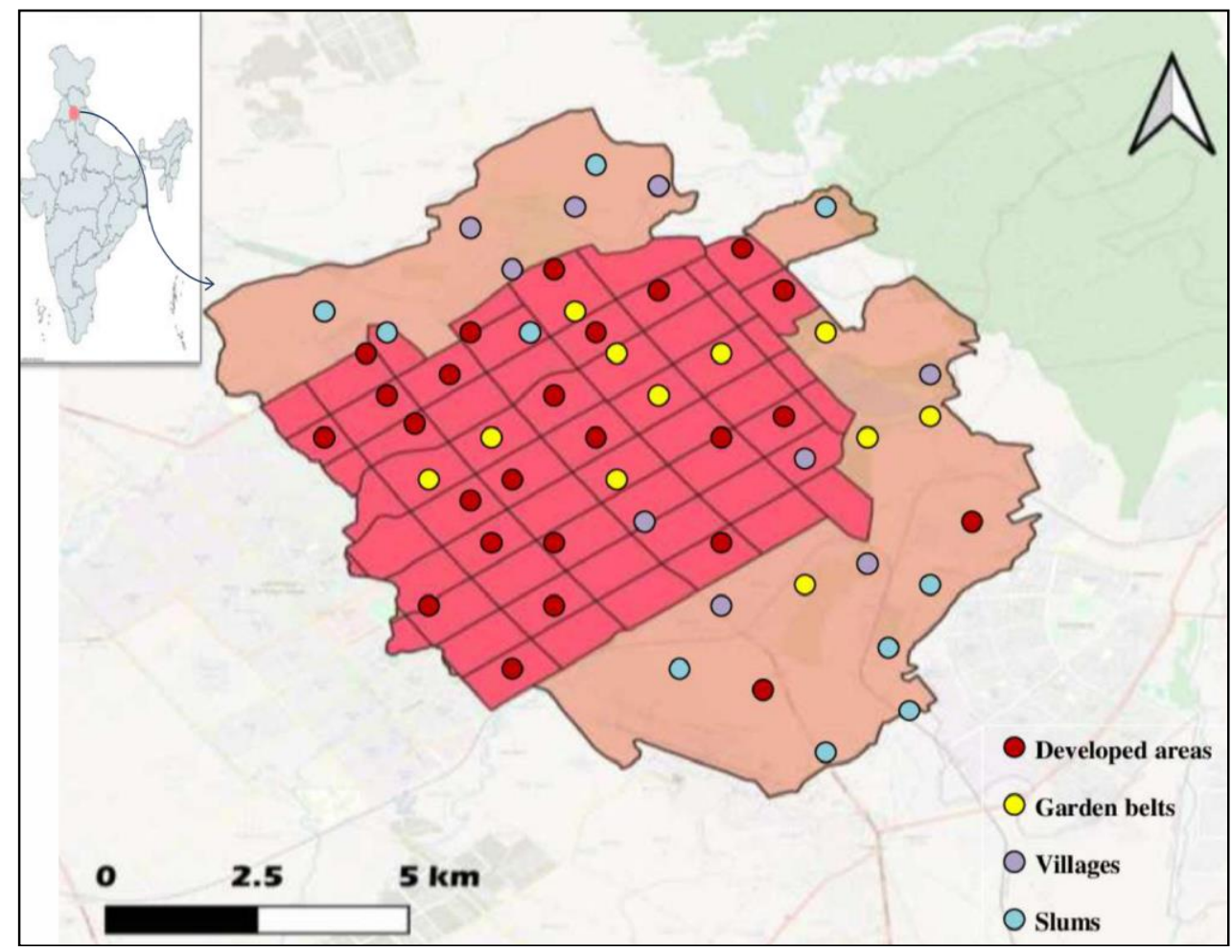




\begin{tabular}{|c|c|c|c|}
\hline Garden Belts & Villages & Slums & Developed Urban areas \\
\hline $\begin{array}{l}\text { 1.Bougainvillea Garden I } \\
\text { 2.Leisure Valley } \\
\text { 3. Zakir Hussain Rose Garden } \\
\text { 4.Fragnance Garden } \\
\text { 5.Terraced Garden } \\
\text { 6.Topiary Garden } \\
\text { 7. Pointsettian \& Ix ora Garden } \\
\text { 8. Botanical Garden (Sec-14) } \\
\text { 9. Hibiscus Garden } \\
\text { 10.Dahlia Garden } \\
\text { 11.Garden of Silence } \\
\text { 12.Botanical Garden (D hanas) } \\
\text { 13.Valley of Animal } \\
\text { 14. Garden of Springs } \\
\text { 15. Garden of Palms (Sec-42) } \\
\text { 16. Bougainvillea Garden II } \\
\text { 17. Japanese Garden } \\
\text { 18.Shanti Kunj } \\
\text { 19. Botanical Garden( Sukhna) } \\
\text { 20.Butterfly Garden } \\
\text { 21 Rose Garden (Sec-14) }\end{array}$ & $\begin{array}{l}\text { 1.Maloya } \\
\text { 2.Nayagaon I } \\
\text { 3.Khuda Ali sher } \\
\text { 4.Dhanas } \\
\text { 5.Kishan Garh } \\
\text { 6.Hallomajara } \\
\text { 7.Shangariwala } \\
\text { 8.Mastgarh } \\
\text { 9.Sarangpur } \\
\text { 10.Kajheri } \\
\text { 11.Mataur } \\
\text { 12.Kumbra } \\
\text { 13.Kaimbra } \\
\text { 14.Kaimbali } \\
\text { 15.Jagatpura } \\
\text { 16.Bairmajra } \\
\text { 17.Behlana } \\
\text { 18.Kishangarh } \\
\text { 19.Saketri } \\
\text { 20.Kaimbwala } \\
\text { 21.Karoran } \\
\text { 22.Karor Upali } \\
\text { 23.Kansal } \\
\text { 24.Mullanpur } \\
\text { 25.Tagon } \\
\text { 26.Khuda Lohora } \\
\text { 27. Khuda Jassu } \\
\text { 28. Daria } \\
\text { 29.Raipur Kalan } \\
\text { 30. Nayagoan II } \\
\text { 31. Nizampur Burail }\end{array}$ & $\begin{array}{l}\text { 1.Khuda Lahora } \\
\text { 2.Mauli Jagran } \\
\text { 3.BapuD ham Colony I } \\
\text { 4.BapuD hamColony II } \\
\text { 5.Burail } \\
\text { 6.Dadu Majra } \\
\text { 7.Sector } 25 \\
\text { 8.Madanpur } \\
\text { 9.Raipur khurd } \\
\text { 10.Makkanmajra } \\
\text { 11.Railway Colony } \\
\text { 12.Palsora }\end{array}$ & $\begin{array}{l}\text { 1.Sector } 4 \\
\text { 2.Sector } 8 \\
\text { 3.Sector } 14 \\
\text { 4.Sector } 15 \\
\text { 5.Sector } 38 \\
\text { 6.Sector } 39 \\
\text { 7.Sector } 46 \\
\text { 8.Sector } 48 \\
\text { 9.Sector } 2 \\
\text { 10.Sector } 9 \\
\text { 11.Sector } 16 \\
\text { 12.Sector } 24 \\
\text { 13.Sector } 34 \\
\text { 14.Sector } 36 \\
\text { 15.Sector } 45 \\
\text { 16.Baltana } \\
\text { 17.Sector } 31 \\
\text { 18.Sector } 40 \\
\text { 19.Bal Bhawan } \\
\text { 20.Mohali } \\
\text { 21.Nada sahib } \\
\text { 22.Panchkula } \\
\text { 23.Zirakpur } \\
\text { 24.Manimajra } \\
\text { 25.Sukhna Lake } \\
\text { 26.New Lake Sec-42 } \\
\text { 27. Mohali } 6 \text { Phase } \\
\text { 28. Mohali } 3 \text { B2 } \\
\text { 29. Sector-19 } \\
\text { 30. Sector } 22 \\
\text { (\& other sectors of Chandigarh) }\end{array}$ \\
\hline
\end{tabular}

Fig 1: Map showing Study areas of Chandigarh and its surroundings (via QGIS mapping)

2.3 Meteorological Data Collection: For meteorological parameters like maximum and minimum temperature, relative humidity and rainfall data during the period June 2017November 2019 was collected on monthly basis from India Meteorology Department, Sector-39, Chandigarh. Average maximum temperature of the last three years was $34.55^{\circ} \mathrm{C}$ while minimum $24.40^{\circ} \mathrm{C}$. Maximum temperature was recorded in the pre-monsoons and early months of monsoons while minimum temperature was recorded during the late post-monsoon period. The average relative humidity and average rainfall for survey period was $65.11 \%$ and $3.86 \mathrm{~mm}$ respectively (Table 1).

2.4 Statistical analysis: The statistical analysis was performed to determine the correlation between climatic factors and JE vector density by using Pearson correlation coefficient. Further, regression analysis including $\mathrm{p}$-value and correlation coefficient (r) was computed by using SPSS ${ }^{\circledR} 16.0$ to test the significant statistical difference between mosquito density and associated climatic factors.

Table 1: Average annual climatic data of Chandigarh during June 2017 to November 2019

\begin{tabular}{|c|c|c|c|c|c|c|}
\hline \multirow{2}{*}{ S.no. } & \multirow{2}{*}{ Year } & \multirow{2}{*}{ Months } & \multicolumn{2}{|c|}{ Temperature $\left({ }^{\circ} \mathbf{C}\right)$} & \multirow{2}{*}{$\begin{array}{c}\text { Relative Humidity } \\
(\%)\end{array}$} & \multirow{2}{*}{$\frac{\text { Average Rainfall }}{(\mathbf{m m})}$} \\
\hline & & & Min Temperature & Max Temperature & & \\
\hline \multirow{3}{*}{1.} & \multirow{3}{*}{2017} & Pre-monsoon (June) & $26.36^{\circ} \mathrm{C}$ & $36.38^{\circ} \mathrm{C}$ & $55.08 \%$ & $4.52 \mathrm{~mm}$ \\
\hline & & Monsoon (July-September) & $25.58^{\circ} \mathrm{C}$ & $33.83^{\circ} \mathrm{C}$ & $74.54 \%$ & $6.95 \mathrm{~mm}$ \\
\hline & & Post-monsoon (October-November) & $14.81{ }^{\circ} \mathrm{C}$ & $29.70{ }^{\circ} \mathrm{C}$ & $66.74 \%$ & $0.0 \mathrm{~mm}$ \\
\hline \multirow{3}{*}{2.} & \multirow{3}{*}{2018} & Pre-monsoon (June) & $26.96^{\circ} \mathrm{C}$ & $37.15^{\circ} \mathrm{C}$ & $57.59 \%$ & $5.66 \mathrm{~mm}$ \\
\hline & & Monsoon (July-September) & $25.34^{\circ} \mathrm{C}$ & $33.12^{\circ} \mathrm{C}$ & $79.05 \%$ & $8.94 \mathrm{~mm}$ \\
\hline & & Post-monsoon (October-November) & $14.53{ }^{\circ} \mathrm{C}$ & $33.5^{\circ} \mathrm{C}$ & $63.43 \%$ & $0.23 \mathrm{~mm}$ \\
\hline \multirow{3}{*}{3.} & \multirow{3}{*}{2019} & Pre-monsoon (June) & $27.07^{\circ} \mathrm{C}$ & $45.07^{\circ} \mathrm{C}$ & $45.00 \%$ & $0.88 \mathrm{~mm}$ \\
\hline & & Monsoon (July-September) & $25.25^{\circ} \mathrm{C}$ & $33.77^{\circ} \mathrm{C}$ & $76.43 \%$ & $6.77 \mathrm{~mm}$ \\
\hline & & Post-monsoon (October-November) & $15.76^{\circ} \mathrm{C}$ & $28.51^{\circ} \mathrm{C}$ & $68.21 \%$ & $0.83 \mathrm{~mm}$ \\
\hline
\end{tabular}

Source: Meteorology Department Chandigarh

3. Results and Discussion
3.1 Species composition: During present investigations, a 
total of 21,970 mosquitoes belonging to 8 genera viz; Culex, Aedes, Armigeres, Verrallina, Mansonia, Anopheles, Coquillettidia and Mimomyia were collected. Out of these, genus Culex was the most dominant with $69.40 \%$ of total catch followed by Aedes (23.18\%), Armigeres (5.62\%), Verrallina (1.16\%), Mansonia (0.26\%), Anopheles $(0.11 \%)$, Coquillettidia $(0.11 \%)$ and Mimomyia $(0.13 \%)$. The genus Culex was represented by 19 species viz; Culex (Culex) quinquefasciatus, Culex (Culex) fuscocephala, Culex (Culex) vagans, Culex (Culex) univittatus, Culex (Culex) theileri, Culex (Culex) hutchinsoni, Culex (Culex) tritaeniorhynchus, Culex (Culex) pseudovishnui, Culex (Culex) vishnui, Culex
(Culex) summorosus, Culex (Culex) whitei, Culex (Oculeomyia) bitaeniorhynchus, Culex (Culex) sitiens, Culex (Oculeomyia) sinensis, Culex (Culex) gelidus, Culex (Culex) whitmorei, Culex (Oculeomyia) luzonensis, Culex (Oculeomyia) infula and Culex (Culex) mimulus. Out of these, 13 species belonging to sitiens group have been found, of which seven are important vectors of Japanese encephalitis in India (Table 2). Hence, keeping in view, the importance of these species in carrying Japanese encephalitis virus, the present studies have been carried out to know the distribution, relative abundance and seasonal prevalence of seven vector species from Chandigarh and its surrounding areas.

Table 2: Composition of species belonging to Culex sitiens group in Chandigarh and its adjoining areas

\begin{tabular}{|c|c|c|c|c|c|}
\hline \multirow{2}{*}{ S. No. } & \multirow{2}{*}{ Species Name } & \multicolumn{3}{|c|}{ Total captured } & \multirow{2}{*}{ Total percentage } \\
\hline & & 2017 & 2018 & 2019 & \\
\hline 1. & Culex (Culex) tritaeniorhynchus $*$ & 3282 & 3564 & 2473 & 76.52 \\
\hline 2. & Culex (Culex) pseudovishnui* & 398 & 512 & 36 & 7.76 \\
\hline 3. & Culex (Culex) vishnui* & 198 & 276 & 54 & 4.33 \\
\hline 4. & Culex (Culex) summurosus & 28 & 441 & 361 & 6.81 \\
\hline 5. & Culex (Culex) whitei & 37 & 1 & - & 0.31 \\
\hline 6. & Culex (Culex) sitiens & 87 & 277 & 112 & 3.90 \\
\hline 7. & Culex (Culex) whitmore $i^{*}$ & 25 & 25 & 5 & 0.45 \\
\hline 8. & Culex (Culex) gelidus* & 36 & 130 & 111 & 2.27 \\
\hline 9. & Culex(Oculeomyia)bitaeniorhynchus* & 92 & 82 & 25 & 1.63 \\
\hline 10. & Culex (Oculeomyia) sinensis & 47 & 38 & 13 & 0.80 \\
\hline 11. & Culex (Oculeomyia) luzonensis & 6 & - & 11 & 0.13 \\
\hline 12. & Culex (Oculeomyia) infula* & 4 & 2 & 4 & 0.08 \\
\hline 13. & Culex (Culex) mimulus & 1 & - & 1 & 0.01 \\
\hline & Total & 4241 & 5352 & 2585 & 12,178 \\
\hline
\end{tabular}

(*) Marked species are vectors of Japanese encephalitis virus in India ${ }^{[4]}$

3.2 Seasonal prevalence and relative abundance of $\mathbf{J E}$ vectors: The relationship of weather parameters like maximum temperature, minimum temperature, relative humidity and rainfall with JE vector population for the three years in transient seasons like pre-monsoon, monsoon and post-monsoon from June 2017 to November 2019 (Table 3) was observed. Highest peaks of most vectors were observed during monsoon to initial post-monsoon while smallest peaks during pre-monsoon (June) and late post-monsoon in almost all ecological habitats (Fig. 3). Out of the three weather variables, the statistically significant values $(p<0.05)$ of JE vectors have been observed with relative humidity $(55 \%-$ $75 \%)$ and rainfall $(4 \mathrm{~mm}-6.9 \mathrm{~mm})$ as compared to temperature during three years (Table 4$)$.

The seasonal distribution of JE vectors reveals the fluctuations in different seasons from June 2017-November 2019. These species appeared in pre-monsoon season (2.67\%) and reach the major peaks during monsoon period $(80.74 \%)$ and decline during post-monsoon season (16.57\%) (Fig. 2). However, monthly distribution of JE vectors has shown different trends throughout survey periods in different ecological habitats of the study area.

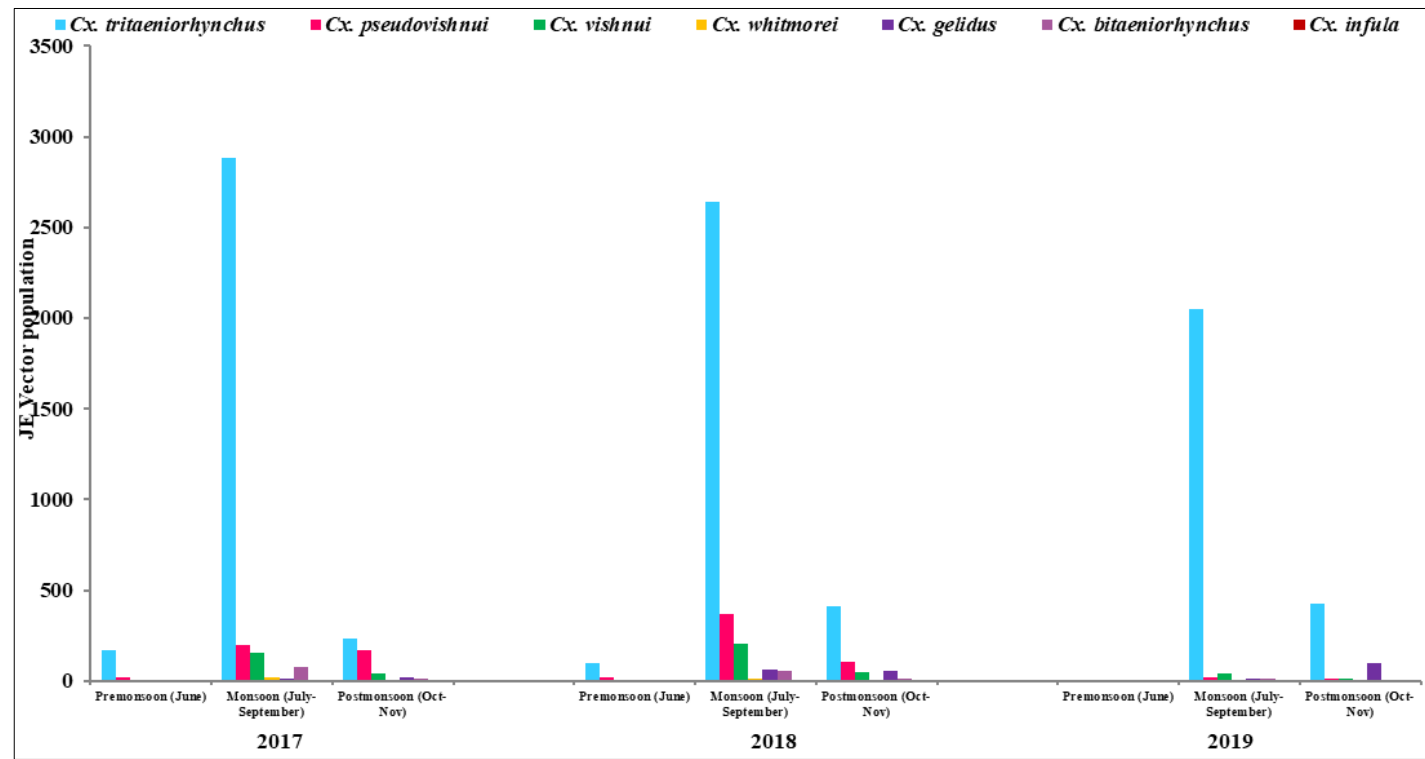

Fig 2: Seasonal abundance of JE vectors in Chandigarh and its surrounding areas

Table 3: Monthly Relationship between JE Vector Populations and Weather Parameters in Chandigarh and its surroundings 


\begin{tabular}{|c|c|c|c|c|c|c|c|c|c|c|c|c|c|}
\hline \multirow[b]{2}{*}{$\begin{array}{l}\text { Study } \\
\text { Years }\end{array}$} & \multirow[b]{2}{*}{$\begin{array}{l}\text { Survey } \\
\text { periods }\end{array}$} & \multicolumn{7}{|c|}{ Total number of JE vector captured } & \multirow[b]{2}{*}{$\begin{array}{c}\text { Total } \\
(\mathrm{n})\end{array}$} & \multicolumn{4}{|c|}{ Weather Parameters (Mean \pm SD) } \\
\hline & & $\begin{array}{c}\text { Cx. } \\
\text { tritaeniorhynchus }\end{array}$ & $\begin{array}{c}\text { Cx. } \\
\text { pseudovishnui }\end{array}$ & $\begin{array}{c}\text { Cx. } \\
\text { vishnui }\end{array}$ & $\begin{array}{c}\text { Cx. } \\
\text { whitmorei }\end{array}$ & $\begin{array}{l}\text { Cx. } \\
\text { gelidus }\end{array}$ & $\begin{array}{c}\text { Cx. } \\
\text { bitaeniorhynchus }\end{array}$ & $\begin{array}{c}\text { Cx. } \\
\text { infula }\end{array}$ & & $\begin{array}{c}\text { Max temp. } \\
\left({ }^{\circ} \mathrm{C}\right)\end{array}$ & $\begin{array}{l}\text { Min temp. } \\
\quad\left({ }^{\circ} \mathrm{C}\right)\end{array}$ & RH & $\begin{array}{c}\text { Rain fall } \\
(\mathbf{m m})\end{array}$ \\
\hline \multirow{3}{*}{2017} & Pre-monsoon & 168 & 24 & 01 & 01 & 01 & 04 & - & 199 & $36.39 \pm 0.01$ & $26.33 \pm 0.04$ & $55 \pm 0.007$ & $4.47 \pm 0.07$ \\
\hline & Monsoon & 2880 & 201 & 155 & 18 & 14 & 75 & 01 & 3344 & $33.83 \pm 0.92$ & $25.58 \pm 2.71$ & $75 \pm 0.04$ & $6.95 \pm 3.43$ \\
\hline & $\begin{array}{c}\text { Post- } \\
\text { monsoon }\end{array}$ & 234 & 173 & 42 & 06 & 21 & 13 & 03 & 492 & $33.31 \pm 4.87$ & $20.43 \pm 4.15$ & $67 \pm 0.04$ & $00 \pm 00$ \\
\hline \multirow{3}{*}{2018} & Pre-monsoon & 99 & 18 & - & - & - & 02 & - & 119 & $37 \pm 0.07$ & $26.96 \pm 0.66$ & $58 \pm 0.004$ & $5.66 \pm 0.11$ \\
\hline & Monsoon & 2644 & 366 & 203 & 15 & 60 & 55 & 01 & 3344 & $33.12 \pm 1.22$ & $25.34 \pm 2.06$ & $79 \pm 0.01$ & $8.94 \pm 1.80$ \\
\hline & $\begin{array}{c}\text { Post- } \\
\text { monsoon }\end{array}$ & 415 & 103 & 48 & 08 & 57 & 15 & 01 & 647 & $33.5 \pm 2.55$ & $14.53 \pm 2.55$ & $63 \pm 0.04$ & $0.23 \pm 0.06$ \\
\hline \multirow{3}{*}{2019} & Pre-monsoon & - & - & - & - & 01 & 01 & - & 02 & $45.07 \pm 0.007$ & $27.07 \pm 0.01$ & $0.45 \pm 0.007$ & $0.81 \pm 0.014$ \\
\hline & Monsoon & 2047 & 22 & 40 & 03 & 12 & 17 & - & 2141 & $33.77 \pm 0.45$ & $25.25 \pm 1.51$ & $76 \pm 0.007$ & $6.78 \pm 3.19$ \\
\hline & $\begin{array}{c}\text { Post- } \\
\text { monsoon }\end{array}$ & 426 & 14 & 14 & 01 & 98 & 05 & - & 558 & $28.51 \pm 3.32$ & $15.76 \pm 3.16$ & $68 \pm 0.07$ & $0.81 \pm 1.12$ \\
\hline & & & & & & & & & & & & & \\
\hline
\end{tabular}

$\mathrm{n}$ - total number of JE vectors in different survey periods and SD-Standard Deviation

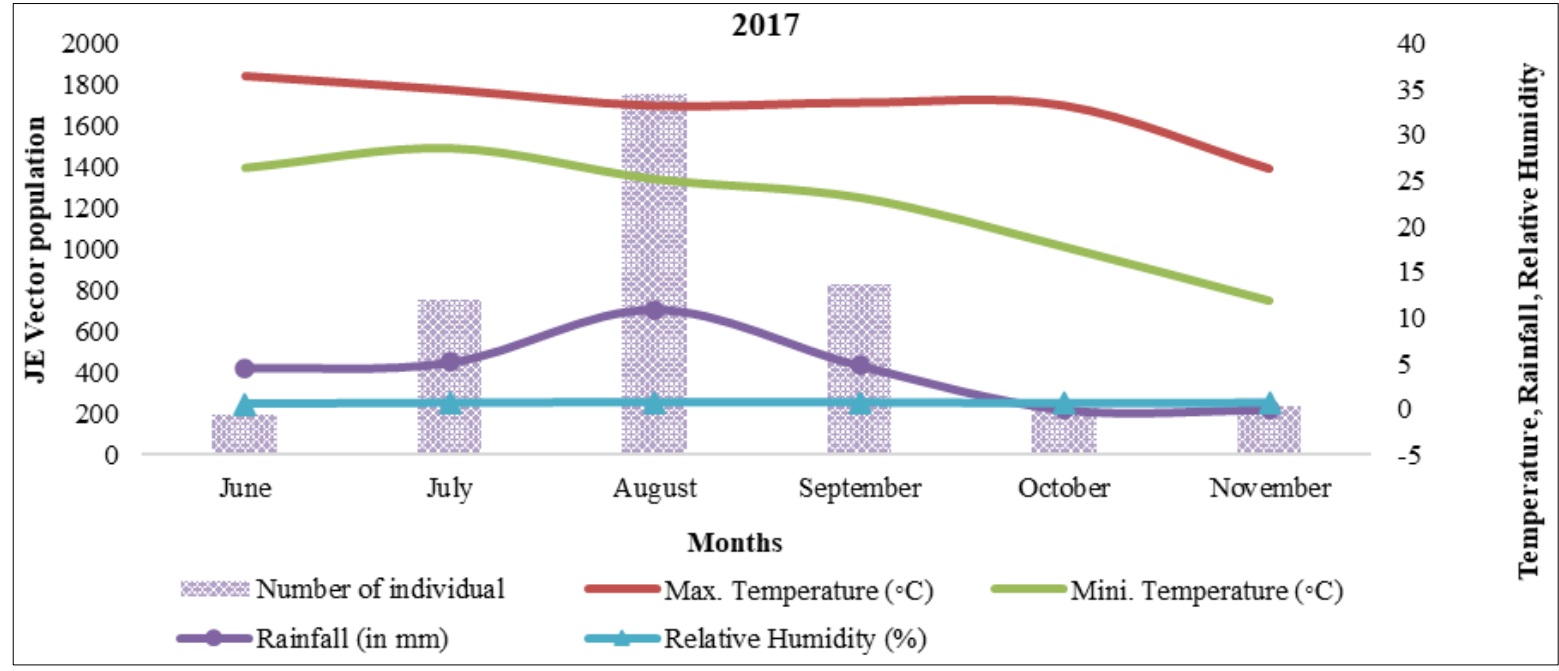

A

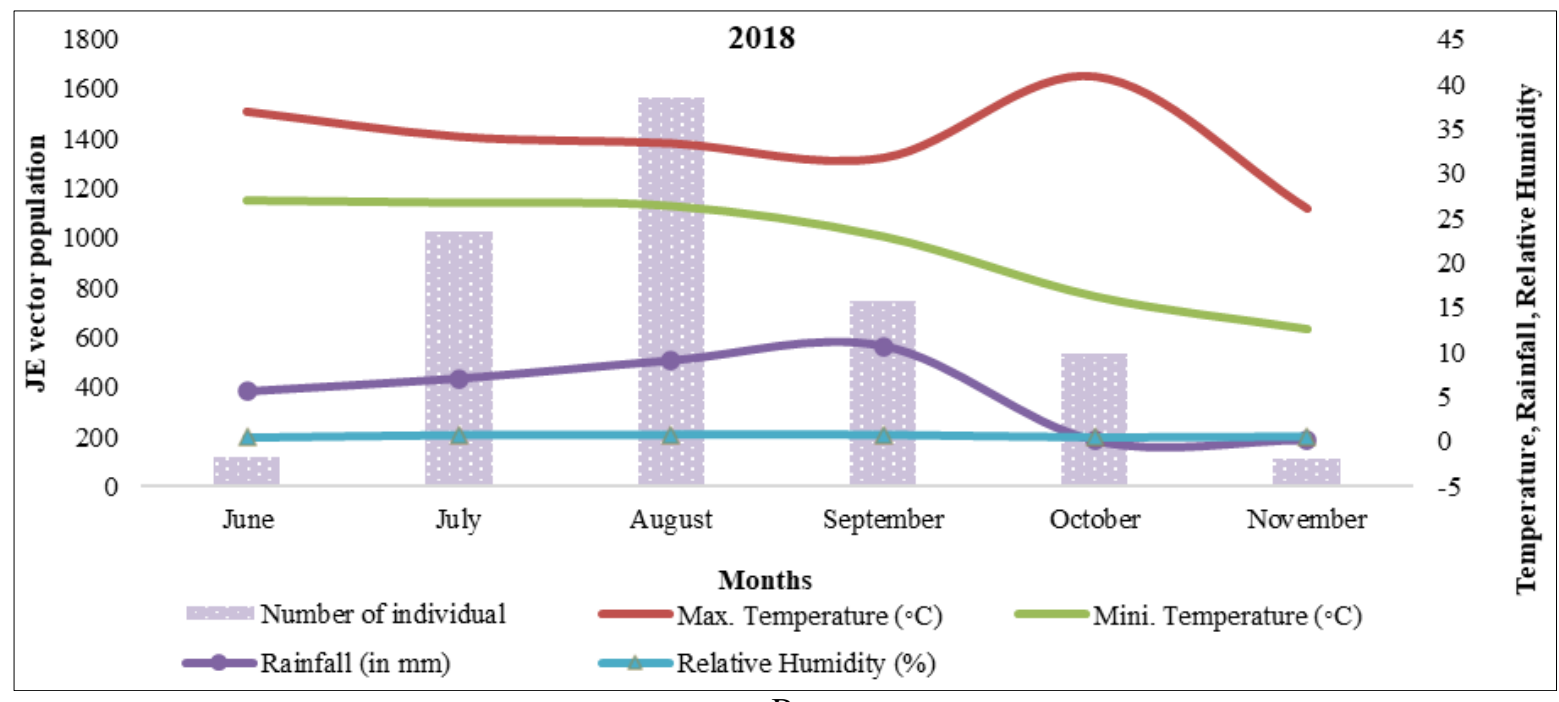




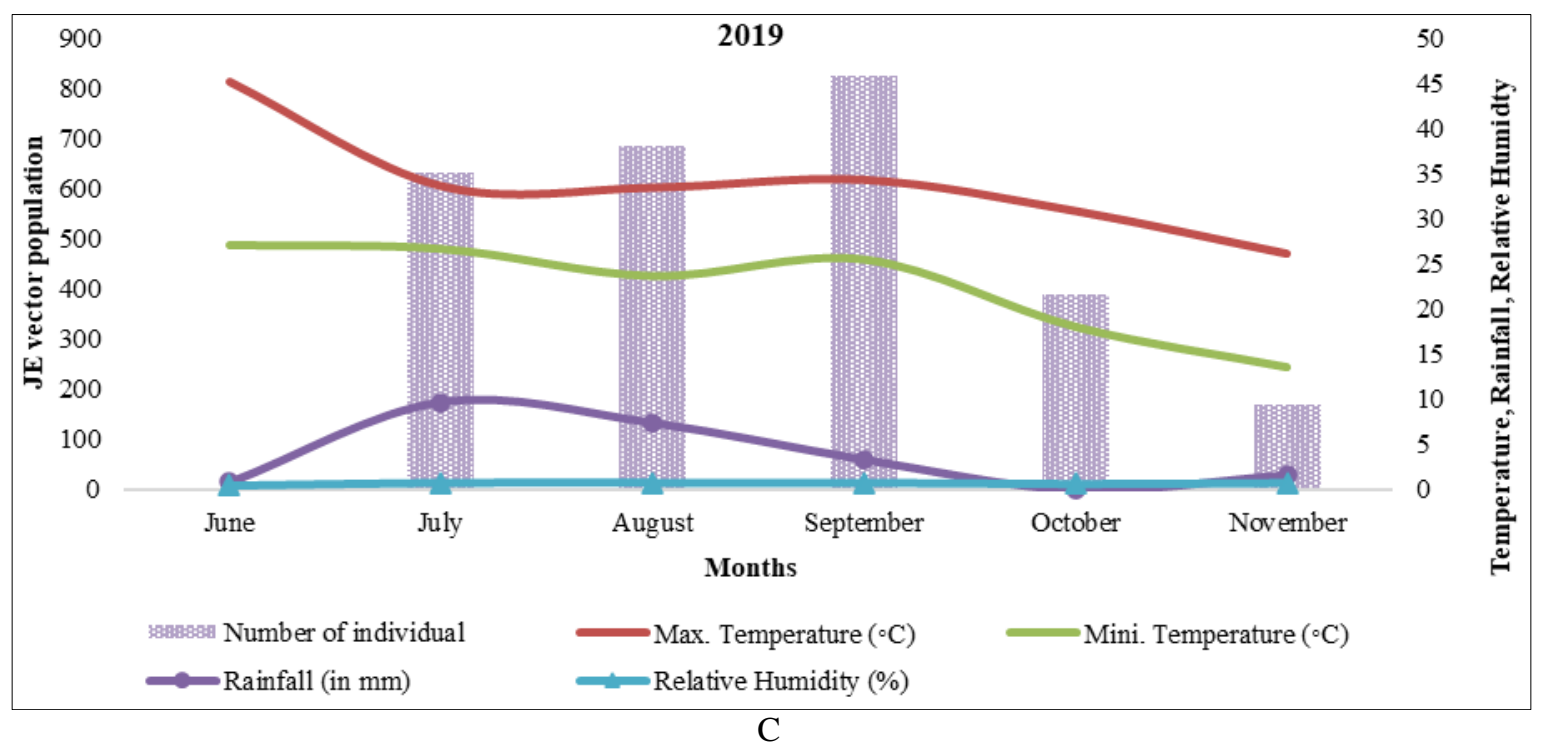

Fig 3: Seasonal occurrence of JE vectors with meteorological parameters like temperature, rainfall and relative humidity in study areas during (A) 2017, (B) 2018, and (C) 2019.

\subsection{Seasonal fluctuation of seven JE vector populationsand its relationship with different meteorological parameters in study habitats \\ 3.3.1 Culex (Culex) tritaeniorhynchus Giles}

The maximum density of Culex tritaeniorhynchus has been recorded from urban areas $(36.66 \%)$, followed by garden belts $(28.07 \%)$, villages $(24.75 \%)$ and slum areas $(10.50 \%)$. In urban areas, the population of $C x$. tritaeniorhynchus started appearing in June (1.17\%), and increased immediately with the onset of monsoon. The maximum adult density of Culex tritaeniorhynchus $(89.69 \%)$ was observed during JulySeptember which declined gradually from October-November (9.1\%). Murty et al., (2010) also observed a high density of Culex tritaeniorhynchus in urban areas as compared to rural areas irrespective of the season ${ }^{[11]}$. Although rice fields are the most preferable breeding sites in villages, its high population dynamics in urban areas than rural areas is pointing towards the most congenial ecological conditions in the vicinity of residential areas.

In gardens, the adult density was $(89.14 \%)$ in JulySeptember, which declined sharply to $9.9 \%$ in OctoberNovember. Their presence in gardens in July-September may be due to the availability of temporary water bodies which developed due to monsoon rains and soon got dried after the rainy season. In slums areas too, the maximum number of individuals were recorded from July-September $(86.10 \%)$ as compared to $12.56 \%$ in October-November. In surrounding villages, the individuals of Culex tritaeniorhynchus were recorded throughout the period of June-November with maximum density seen in July-September (73\%) and $18.16 \%$ in October-November. Its availability in pre-monsoon, monsoon and post-monsoon season in villages may be due to its preferences to breed in rural settings in rice fields, ground pools, ponds with aquatic vegetation and also due to the presence of a variety of hosts like cattle, birds, horses, pigs and other domestic animals.

$C x$. tritaeniorhynchushas showed strong positive correlation between abundance and relative humidity $(p<0.05)$ in 2017 and with lag rainfall $(p<0.05)$ both in 2018-2019 (Table 5). Out of all ecological habitats, a strong positive correlation has been observed between abundance and relative humidity in villages $(p<0.05)$ and slums $(p<0.05)$ (Table 6).

$C x$. tritaeniorhynchus is considered an important vector of Japanese encephalitis (JE) in India and also in many countries of Southeast Asia. Cx. tritaeniorhynchus has yielded total 79 JE isolations viz; 9 virus isolations from Vellore (Tamil Nadu) and Kolar (Karnataka), 2 from Mandya (Karnataka), 58 from Cuddalore (Tamil Nadu), 7 from Kuttanadu (Kerala), 1 from Gorakpur of Uttar Pradesh, North India and 2 from Karnataka ${ }^{[12-16]}$. So far, incidence of JE has been reported from 15 states of India ${ }^{[17]}$.

\subsubsection{Culex (Culex) vishnui Theobald}

The adult density of $C x$. vishnui was also observed maximum in urban areas (42.61\%), gardens (24.43\%), villages $(24.24 \%)$ and in slums $(8.71 \%)$. In urban areas, the maximum percentage of Cx. vishnui $(88 \%)$ was recorded during JulySeptember as compared to $12 \%$ in October-November. Similarly in gardens, this species was recorded as $79.06 \%$ in July-September, which decreased to $20.93 \%$ in OctoberNovember. In villages too, it was $72.65 \%$ in July-September and decreased to $26.56 \%$ in October-November. In slums, during July-September, the individuals obtained were $58.69 \%$ which decreased to $41.30 \%$ during October-November. During present studies, a strong correlation has been observed between abundance of $C x$. vishnui and maximum temperature in developed areas $(p<0.05)$, minimum temperature in slums $(p<0.05)$ while, relative humidity in villages $(p<0.05)$. However, no positive correlation has been observed between abundance and weather parameters in garden belts $(p>0.05)$ of Chandigarh (Table 6).

In 2013, the Department of Medical Parasitology, PGI conducted a survey on medically important mosquitoes and reported the presence of $C x$. vishnui in large numbers in the vicinity of houses of Dhanas villages and Sector 25 (unpublished data). The breeding places of $C x$. vishnui are very similar to $C x$. tritaeniorhynchus ${ }^{[18]}$ and both the species can be found in association with one another. Culex vishnui is another important vector of Japanese encephalitis in India. So far, 30 virus isolations have been made from Culex vishnui in Tamil Nadu, Karnataka and West Bengal ${ }^{[4]}$. 


\subsubsection{Culex (Culex) pseudovishnui Colless}

The adult density of Culex pseudovishnui also followed a similar pattern to Culex vishnui and Culex tritaenorhynchus. The maximum number of individuals of $C x$. pseudovishnui were observed in urban areas $(43.96 \%)$ followed by surrounding villages $(22.45 \%)$, slums $(18.96 \%)$ and gardens (14.61\%). In urban areas, $72.53 \%$ adult density of $C x$. pseudovishnui was obtained during July-September which reduced to $27.22 \%$ in October-November. In gardens, $76.81 \%$ of Cx. pseudovishnui was obtained during July-September. In villages, $45.75 \%$ of density was found in July-September followed by $39.15 \%$ in October-November. In slum areas, $55.7 \%$ of density was noticed in July-September while, it was $40.22 \%$ in October-November. A similar pattern for the prevalence of $C x$. pseudovishnui which showed peak in August during the period of an epidemic of JE has been made in Goa ${ }^{[19]}$. During present investigations, a strong positive correlation of $C x$. pseudovishnui with minimum temperature has been observed in developed urban areas $(p<0.05)$, maximum temperature in slums $(p<0.05)$ and with relative humdity in villages $(p<0.05)$ around Chandigarh. However, no significant correlation of weather parameters with abundnace of $C x$. pseudovishnui in garden belts has been seen (Table 6).

Culex pseudovishnui is also a potential vector of JE in India as total eight JE virus from Kolar (Karnataka) and Goa have been isolated so far ${ }^{[4,19,20]}$. The occurence of three vector species of $C x$. vishnui subgroup viz; $C x$. vishnui, $C x$. pseudovishnui and $C x$. triateniorhynchus has been reported along with various intraspecific variations from Chandigarh province ${ }^{[21,22]}$. All the three species belonging to $C x$. vishnui subgroup prefer to breed in ground pools, ponds, wells, ditches, puddles containing fresh or polluted water with grasses and aquatic vegetation ${ }^{[7]}$. The breeding habits of $C x$. pseudovishnui are very similar to $C x$. tritaeniorhynchus and $C x$. vishnui. It breeds in freshwater ground pools, rice fields and stream pools ${ }^{[23]}$. Reuben (1971) reported the presence of larvae in rice fields when plant reached $0.3 \mathrm{~m}$ in height ${ }^{[20]}$

\subsubsection{Culex (Culex) whitmorei Giles}

Cx. whitmore $i$ was obtained $32.72 \%$ in villages and $30.90 \%$ in urban areas, $29.09 \%$ in gardens while in slums it was $7.27 \%$. In villages, the maximum percentage was found in JulySeptember $(83.33 \%)$ which reduced to $11.1 \%$ in OctoberNovember. In urban areas too, the high density was observed in July-September (70.58\%), which declined to $29.41 \%$ in October-November. However, in slums areas a different trend has been seen. These were highest i.e., $75 \%$ during post monsoon period (October-November). In addition to this, in almost all habitats, maximum female specimens of $C x$. whitmorei were found, i.e., about $0.5 \%$ of total catch. Earlier workers have also reported only $5 \%$ of adults of total catch ${ }^{[20,}$ 25, 26]. During present work, strong correlation with maximum temperature $(p<0.05)$ has been found in urban areas. However, other meteorological parameters like minimum temperature, rainfall and relative humidity have shown no significant relation with abundance in villages, garden belts and slums (Table 6).

The breeding places of $C x$. whitmorei are freshwater ground pools, puddles, ditches in rice fields with aquatic vegetation ${ }^{[18]}$. It is a chief vector of JE in India, a total of four JE virus isolations have been made in India so far out of which, two were from Vellore (Tamil Nadu) and Krishna (AP) and two from Kolar (Kar) and West Bengal ${ }^{[4,18]}$.

\subsubsection{Culex (Culex) gelidus Theobald}

The abundance of $C x$. gelidus was $36.23 \%$ in villages followed $32.97 \%$ in gardens, $27.89 \%$ in urban areas and slum areas it was $2.87 \%$. In urban areas, the percentage of $C x$. gelidus was $15.58 \%$ during July-September which increased to $84.41 \%$ during post-monsoon season i.e., OctoberNovember. However, in villages, these were abundant during July-September $(60 \%)$ and reduced to $39 \%$ in OctoberNovember. In slums, these were found only during postmonsoon season $(87.5 \%)$. In gardens too, highest peak density of adults was obtained in post-monsoon season (85.71\%). Hence, except in villages, this species was available in postmonsoon periods in most areas of Chandigarh. During these studies, a strong correlation between minimum temperature and abundance of $C x$. gelidus $(p<0.05)$ was observed in 2019 whereas, other parameters like relative humidity and rainfall have not been found to be correlated with its abundance (Table 5). Out of four ecological habitats, Cx. gelidus has shown no significant correlation between abundance and all meteorological parameters in developed urban areas, villages, gardens and slums in and around Chandigarh (Table 6).

The corresponding facts regarding abundance of $C x$. gelidus in the post-monsoon period was also observed in Bareilly, Uttar Pradesh ${ }^{[27]}$. It might be due to the presence of swampy water bodies as this species prefers to breed in marshy water containing abundant aquatic vegetation or in muddy pools with a high concentration of organic matter ${ }^{[7,28]}$. They also observed that accumulated manures and stagnant water left over in the paddy fields facilitates $C x$. gelidus breeding. Murty et al., (2010) observed predominantly high percentage $(68.05 \%)$ in urban areas and least percentage in rural areas of Kurnool district of Andhra Pradesh [11]. Philip et al., (2016) mentioned the gradual replacement of $C x$. tritaeniorhynchus with $C x$. gelidus in urban and semi-urban areas ${ }^{[29]}$.

$C x$. gelidus has been reported from various states of India viz; Maharashtra, Goa, Rajasthan, Karnataka, Kerala, Tamil Nadu, Andhra Pradesh, West Bengal and Assam. But, from Chandigarh and its adjoining areas,it has been observedwith various variations in morphology. In India, earlier studies carried out on $C x$. gelidus showed the negligible percentage of the total population of mosquitoes while, in recent years, it has increased to more than $50 \%$ of the total mosquito population in the same area (NIV Annual report 2009-2010, 2012-2013).

Cx. gelidus has shown wide susceptibility to arboviruses associated with family Togaviridae, Flaviviridae, Rhabdoviridae and Bunyaviridae. The natural isolations of Getah (GETV), Japanese encephalitis virus (JEV), Ross River (RRV) and Tembusu virus have already been documented suggesting their susceptibility to these viruses [30]. Recent experimental studies have also shown that the mosquitoes are susceptible to Chikungunya virus (CHIKV), Chandipura virus (CHPV) and Chittoor (CHITV, Batai group) virus in Pune (Sudeep, unpublished data). Many Isolations of JEV have also been made from $C x$. gelidus in India. A total number of $8 \mathrm{JE}$ isolations have been made of which 5 isolations are from Cuddalore district of Tamil Nadu and 3 from Mandya in Karnataka ${ }^{[4,15]}$.

\subsubsection{Culex (Oculeomyia) bitaeniorhynchus Giles}

Culex bitaeniorhynchus was found in almost all the ecological 
habitats with maximum density in urban areas $(40.7 \%)$ followed by gardens (38.3\%), villages (14.4\%), slums $(6.46 \%)$. In urban areas, the adults were abundant during July-September $(82.92 \%)$ while, got decreased to $15.86 \%$ during October- November. In gardens too, almost $79.22 \%$ of adults were reported during July-September which reduced drastically to $19.48 \%$ in October-November. In villages, these were $62.06 \%$ during July-September (monsoon) and decreased to $24 \%$ in October-November. In slums, $53.84 \%$ in monsoon period (July-September) while, reduced to $38 \%$ in the post-monsoon period (October-November). As far as its realtion with weather parameter is concerned, it showed a strong positive correlation with relative humidity and lag rainfall but no significance in relation with temperature in 2017 (Table 5). Out of 4 habitats, strong positive correlation $(p<0.05)$ was observed in garden belts but no significant correlation in urban areas, villages and slums around Chandigarh (Table 6).

During present investigations, two forms of Culex bitaeniorhynchus i.e., 'typical' and 'tenax' form has also been observed along with various intraspecific variants. Culex bitaeniorhynchus breeds in swamps, ponds, irrigation ditches filled with a dense mass of filamentous green algae ${ }^{[7,18]}$. Culex bitaeniorhynchus is important from viewpoint of spreading various diseases like Japanese encephalitis and filariasis in tropical and subtropical regions of Asia. First JE virus isolation from Culex bitaeniorhynchus was reported from Malaysia ${ }^{[31]}$. In Korea, it has also been incriminated as a possible vector of Japanese encephalitis ${ }^{[32]}$. Further, 3 isolations of JE virus have been made in Karnataka and West Bengal of India ${ }^{[4]}$. Iyengar (1938) reported bitaeniorhynchus naturally infected with Wuchereria bancrofti in the oriental region, Travancore, India ${ }^{[33]}$.

\subsubsection{Culex (Oculeomyia) infula Theobald}

$C x$. infula was reported at its highest density in villages $(83.33 \%)$, followed by urban areas $(1.66 \%)$ whereas not even a single adult was found in gardens and slum areas, During the present investigations, $80 \%$ of catch was recorded in villages during post-monsoon seasons while $20 \%$ in late monsoon period. In urban areas, only one adult was recorded during late monsoon period. $C x$. infula has showed strong positive correlation $(p<0.05)$ with rainfall whereas no significant correlation with other meteorological parameters in all of the ecological habitats in and around Chandigarh (Table 5, 6).

$C x$. infula mainly feeds on cattle but a few fraction on birds and humans as larvae are available in water courses with high content of algae ${ }^{[34]}$. Cx. infula is also considered as an important vector of JE, as total of $6 \mathrm{JE}$ virus isolations were made from $C x$. infula viz; 1 from Madurai (TN) and 5 from Cuddalore $(\mathrm{TN})^{[35,36]}$.

Table 4: Analysis of Pearson's correlation coefficient ( $r$-value) between the meteorological parameters and JE vectors population density

\begin{tabular}{|c|c|c|c|c|c|c|}
\hline \multirow{2}{*}{ Meteorological parameters } & \multicolumn{2}{|c|}{$\mathbf{2 0 1 7}$} & \multicolumn{2}{|c|}{$\mathbf{2 0 1 8}$} & \multicolumn{2}{c|}{$\mathbf{2 0 1 9}$} \\
\cline { 2 - 7 } & r-value & p-value & r-value & p-value & r-value & p-value \\
\hline Maximum Temperature $\left({ }^{\circ} \mathrm{C}\right)$ & 0.15 & 0.76 & 0.08 & 0.87 & -0.26 & 0.60 \\
\hline Minimum Temperature $\left({ }^{\circ} \mathrm{C}\right)$ & 0.44 & 0.37 & 0.52 & 0.28 & 0.33 & 0.52 \\
\hline Relative Humidity $(\%)$ & 0.90 & $0.01^{*}$ & 0.79 & $0.05^{*}$ & 0.63 & 0.17 \\
\hline Rainfall $(\mathrm{mm})$ & 0.78 & $0.05^{*}$ & 0.62 & 0.18 & 0.76 & $0.05^{*}$ \\
\hline
\end{tabular}

(Pearson's correlation coefficient (r); Significant $\mathrm{p}$ value* (confidence interval of $95 \%) \mathrm{p}<0.05$ considered to be statistically significant)

Table 5: Pearson's correlation coefficient (r) of most JE vectors with meteorological parameters and their significant (p) value

\begin{tabular}{|c|c|c|c|c|c|c|c|c|}
\hline \multirow{2}{*}{ Species } & \multicolumn{2}{|c|}{ Maximum temp. $\left(\mathrm{T}_{\max }\right)$} & \multicolumn{2}{|c|}{ Minimum temp. $\left(T_{\min }\right)$} & \multicolumn{2}{|c|}{ Rainfall } & \multicolumn{2}{|c|}{ Relative Humidity } \\
\hline & $\mathbf{r}$ & p-value & $\mathbf{r}$ & p-value & $\mathbf{r}$ & p-value & $\mathbf{r}$ & p-value \\
\hline \multicolumn{9}{|c|}{2017} \\
\hline Culex tritaeniorhynchus & 0.21 & 0.68 & 0.51 & 0.29 & 0.71 & 0.08 & 0.92 & $0.008 *$ \\
\hline Cx. pseudovishnui & -0.45 & 0.35 & -0.48 & 0.32 & 0.15 & 0.77 & 0.54 & 0.26 \\
\hline Cx. vishnui & -0.02 & 0.96 & 0.09 & 0.86 & 0.73 & 0.09 & 0.67 & 0.13 \\
\hline Cx. whitmorei & -0.39 & 0.43 & -0.66 & 0.14 & 0.98 & 0.85 & -0.62 & 0.18 \\
\hline Cx. gelidus & 0.00 & 0.99 & -0.27 & 0.95 & 0.57 & 0.23 & 0.24 & 0.63 \\
\hline Cx. bitaeniorhynchus & 0.12 & 0.81 & 0.45 & 0.36 & 0.81 & $0.04 *$ & 0.87 & $0.02 *$ \\
\hline Cx. infula & -0.28 & 0.58 & -0.49 & 0.31 & -0.24 & 0.64 & -0.71 & 0.11 \\
\hline \multicolumn{9}{|c|}{2018} \\
\hline Culex tritaeniorhynchus & 0.03 & 0.95 & 0.50 & 0.30 & 0.77 & $0.007 *$ & 0.64 & 0.16 \\
\hline Cx.pseudovishnui & 0.22 & 0.66 & 0.35 & 0.49 & 0.30 & 0.55 & 0.10 & 0.84 \\
\hline Cx. vishnui & 0.21 & 0.68 & 0.45 & 0.36 & 0.69 & 0.12 & 0.45 & 0.36 \\
\hline$C x$. whitmorei & -0.18 & 0.71 & -0.49 & 0.32 & 0.01 & 0.97 & 0.13 & 0.79 \\
\hline Cx. gelidus & 0.47 & 0.34 & -0.02 & 0.96 & 0.31 & 0.54 & 0.19 & 0.71 \\
\hline Cx. bitaeniorhynchus & 0.28 & 0.58 & 0.36 & 0.47 & 0.70 & 0.11 & 0.61 & 0.19 \\
\hline Cx. infula & 0.37 & 0.46 & -0.30 & 0.56 & -0.02 & 0.96 & -0.01 & 0.98 \\
\hline \multicolumn{9}{|c|}{2019} \\
\hline Culex tritaeniorhynchus & -0.20 & 0.69 & 0.39 & 0.43 & 0.75 & $0.018^{*}$ & 0.66 & 0.14 \\
\hline Cx. pseudovishnui & -0.60 & 0.19 & -0.28 & 0.58 & -0.007 & 0.98 & 0.68 & 0.13 \\
\hline Cx. vishnui & -0.37 & 0.46 & 0.94 & 0.86 & 0.61 & 0.19 & 0.75 & 0.08 \\
\hline Cx. whitmorei & -0.62 & 0.18 & -0.86 & $0.02 *$ & -0.02 & 0.95 & -0.62 & 0.18 \\
\hline Cx. gelidus & -0.10 & 0.84 & 0.27 & 0.60 & 0.33 & 0.52 & 0.06 & 0.89 \\
\hline Cx. bitaeniorhynchus & -0.15 & 0.76 & 0.19 & 0.71 & 0.58 & 0.22 & 0.24 & 0.63 \\
\hline Cx. infula & 0.03 & 0.95 & 0.27 & 0.59 & 0.29 & $0.05 *$ & -0.06 & 0.90 \\
\hline
\end{tabular}


Table 6: Statistical analysis of Pearson's correlation coefficient (r) between weather parameters and Population density (PD) of JE vectors from four ecological

\begin{tabular}{|c|c|c|c|c|c|c|c|c|}
\hline \multirow[b]{2}{*}{ Species } & \multicolumn{2}{|c|}{ Developed urban area } & \multicolumn{2}{|c|}{ Villages } & \multicolumn{2}{|c|}{ Garden belt } & \multicolumn{2}{|c|}{ Slums } \\
\hline & $\mathrm{r}$ & $\mathrm{p}$-value & $\mathrm{r}$ & $\mathrm{p}$-value & $\mathrm{r}$ & $\mathrm{p}$-value & $\mathrm{r}$ & $\mathrm{p}$-value \\
\hline \multicolumn{9}{|l|}{ Culex tritaeniorhynchus } \\
\hline Mean $\mathrm{T}_{\max } v s \mathrm{PD}$ & -0.67 & 0.53 & -0.62 & 0.56 & 0.22 & 0.98 & -0.67 & 0.52 \\
\hline Mean $\mathrm{T}_{\min } v s \mathrm{PD}$ & -0.27 & 0.82 & -0.90 & 0.27 & -0.42 & 0.72 & -0.93 & 0.23 \\
\hline Mean RH\% vs PD & -0.13 & 0.91 & 1.00 & $0.01 *$ & 0.75 & 0.45 & 0.99 & $0.02 *$ \\
\hline Mean Rainfall $v s$ PD & -0.32 & 0.07 & 0.98 & 0.10 & 0.86 & 0.33 & 0.97 & 0.14 \\
\hline \multicolumn{9}{|l|}{ Cx. pseudovishnui } \\
\hline Mean $\mathrm{T}_{\max } v s \mathrm{PD}$ & -0.87 & 0.32 & -0.61 & 0.57 & 0.06 & 0.96 & 0.99 & $0.002 *$ \\
\hline Mean $\mathrm{T}_{\min } v s \mathrm{PD}$ & -0.99 & $0.03 *$ & -0.90 & 0.28 & -0.38 & 0.74 & -0.89 & 0.289 \\
\hline Mean RH\% vs PD & 0.93 & 0.22 & 1.00 & $0.02 *$ & 0.72 & 0.48 & 0.64 & 0.55 \\
\hline Mean Rainfall $v_{s}$ PD & 0.85 & 0.34 & 0.98 & 0.10 & 0.84 & 0.36 & 0.49 & 0.67 \\
\hline \multicolumn{9}{|l|}{ Cx. vishnui } \\
\hline Mean $\mathrm{T}_{\max } v s \mathrm{PD}$ & -0.99 & $0.02 *$ & -0.64 & 0.55 & 0.43 & 0.97 & -0.94 & 0.21 \\
\hline Mean $\mathrm{T}_{\min } v s \mathrm{PD}$ & -0.91 & 0.26 & -0.91 & 0.26 & -0.40 & 0.73 & -0.99 & $0.05^{*}$ \\
\hline Mean RH\% vs PD & 0.61 & 0.53 & 0.99 & $0.001 *$ & 0.73 & 0.47 & 0.86 & 0.33 \\
\hline Mean Rainfall $v s$ PD & 0.51 & 0.65 & 0.98 & 0.12 & 0.85 & 0.35 & 0.75 & 0.45 \\
\hline \multicolumn{9}{|l|}{ Cx. whitmorei } \\
\hline Mean $\mathrm{T}_{\max } v s \mathrm{PD}$ & -0.99 & $0.03 *$ & -0.85 & 0.34 & 0.04 & 0.97 & -0.98 & 0.12 \\
\hline Mean $\mathrm{T}_{\min } v s \mathrm{PD}$ & -0.91 & 0.25 & -0.54 & 0.63 & -0.40 & 0.73 & -0.78 & 0.42 \\
\hline Mean RH\% vs PD & 0.68 & 0.52 & 0.16 & 0.89 & 0.73 & 0.47 & 0.47 & 0.68 \\
\hline Mean Rainfall $v s$ PD & 0.53 & 0.64 & -0.02 & 0.98 & 0.84 & 0.35 & 0.30 & 0.80 \\
\hline \multicolumn{9}{|l|}{ Cx. gelidus } \\
\hline Mean $\mathrm{T}_{\max } v s \mathrm{PD}$ & 0.99 & 0.08 & -0.16 & 0.89 & 0.97 & 0.15 & -0.64 & 0.55 \\
\hline Mean $\mathrm{T}_{\min } v s \mathrm{PD}$ & 0.82 & 0.37 & -0.58 & 0.60 & 0.76 & 0.44 & -0.24 & 0.84 \\
\hline Mean RH\% vs PD & -0.53 & 0.64 & 0.85 & 0.34 & -0.43 & 0.71 & -0.17 & 0.89 \\
\hline Mean Rainfall vs PD & -0.36 & 0.76 & 0.94 & 0.22 & -0.26 & 0.83 & -0.35 & 0.77 \\
\hline \multicolumn{9}{|l|}{ Cx. bitaeniorhynchus } \\
\hline Mean $\mathrm{T}_{\max } v s \mathrm{PD}$ & -0.99 & 0.08 & -0.86 & 0.34 & -0.67 & 0.53 & -0.72 & 0.47 \\
\hline Mean $\mathrm{T}_{\min } v s \mathrm{PD}$ & -0.94 & 0.20 & 0.54 & 0.63 & -0.93 & 0.23 & -0.95 & 0.18 \\
\hline Mean RH\% vs PD & 0.74 & 0.46 & 0.16 & 0.89 & 0.99 & $0.02 *$ & 0.99 & 0.07 \\
\hline Mean Rainfall vs PD & 0.60 & 0.59 & -0.02 & 0.98 & 0.97 & 0.14 & 0.95 & 0.19 \\
\hline \multicolumn{9}{|l|}{ Cx. infula } \\
\hline Mean $\mathrm{T}_{\max } v s \mathrm{PD}$ & -0.01 & 0.99 & -0.95 & 0.18 & - & - & - & - \\
\hline Mean $\mathrm{T}_{\min } v s$ PD & -0.45 & 0.69 & -0.73 & 0.47 & - & - & - & - \\
\hline Mean RH\% vs PD & 0.77 & 0.43 & 0.39 & 0.74 & - & - & - & - \\
\hline Mean Rainfall vs PD & 0.87 & 0.31 & 0.21 & 0.86 & - & - & - & - \\
\hline
\end{tabular}

Pearson's correlation coefficient (r); Significant $\mathrm{p}$ value* (confidence interval of $95 \%) p<0.05$ considered to be statistically significant, PDPopulation Density

\section{Conclusions}

The present study has been done keeping in view the importance of JE vector species and their relation with meteorological factors in the divided ecological habitats of the study area. The present analysis has shown that suitable ecological conditions are available for the establishment of these seven JE vectors in almost all ecological habitats i.e., developed urban areas, villages, garden belts and slums of study areas. These vector populations have shown highest density in July-September (monsoon period) except $C x$. gelidus and $C x$. infula which were recorded maximum in post-monsoon months. As far as weather parameters are concerned, statistically significant values $(p<0.05)$ have been observed with relative humidity $(55 \%-75 \%)$ and rainfall $(4 \mathrm{~mm}-6.9 \mathrm{~mm})$. Since the information about distribution, seasonal prevalence and relative abundance of JE vectors in and around Chandigarh was not available, the present investigations will be immensely beneficial to know the dynamics of Japanese encephalitis in this area and to forecast the outbreak of the disease and its control well in time.

\section{Acknowledgments}

The authors are highly thankful to DST-SERB for providing financial grant in the form of Core Research project (EMR/2016/003185) under which the present work has been carried out.

\section{References}

1. Wang H, Liang G. Epidemiology of Japanese encephalitis: past, present, and future prospects. Therapeutics and Clinical Risk Management. 2015;11:435-448.

2. Kabilan L, Rajendran R, Arunachalam N, Ramesh S, Srinivasan S, Samuel PP, et al. Japanese encephalitis in India: an overview. Indian J Pediatr. 2004;71(7):609-615.

3. Kumari R, Kumar K, Rawat A, Singh G, Yadav NK, Chauhan LS. First indigenous transmission of Japanese Encephalitis in urban areas of National Capital Territory 
of Delhi, India. Trop Med Int Health 2013;18(6):743-749.

4. National Vector Borne Disease Control Programme. https://nvbdcp.gov.in. 29 February, 2021.

5. Barraud PJ. Family Culicidae. Tribes Megarhinini and Culicini. The Fauna of British India, including Ceylon and BurmaDiptera: Culicidae, V. London: Taylor \& Francis, 1934, 1-463.

6. Sirivanakarn S. The forms of Culex (Culex) bitaeniorhynchus Giles in Southeast Asia. Mosq. Syst 1973;5(3):235-251.

7. Sirivanakarn S. Medical entomology studies-III. A revision of the subgenus Culex in the Oriental region (Diptera: Culicidae). Contr. Am. Entomol. Inst. 1976;12:1-272.

8. Reuben R, Tewari SC, Hiriyan J, Akiyama J. Illustrated keys to species of Culex (Culex) associated with Japanese encephalitis in Southeast Asia (Diptera: Culicidae). Mosq Syst 1994;26(2):75-96.

9. Das BP. Pictorial Key to Common Species of Culex (Culex) Mosquitoes Associated with Japanese Encephalitis Virus in India. In: Mosquito Vectors of Japanese Encephalitis Virus from Northern India. Springer Briefs in Animal Sciences. Springer, India, 2013, 25-42.

10. Siverly RE, Shroyer DA. Illustrated key to the genitalia of male mosquitoes of India. Mosq. Syst 1974;6(3):167200.

11. Murty US, Rao MS, Arunachalam N. The effects of climatic factors on the distribution and abundance of Japanese encephalitis vectors in Kurnool district of Andhra Pradesh, India. J Vector Borne Dis 2010;47(1):26-32.

12. Carey DE, Reuben R, Myers RM. Japanese encephalitis studies in Vellore, south India. Part 1. Virus isolation from mosquitoes. Indian J Med Res 1968;56(9):13091319.

13. Carey DE, Reuben R, Myers RM. Japanese encephalitis studies in Vellore, South India. Part V. Experimental infection and transmission. Indian J Med Res 1969;57(2): 282-289.

14. Chakravarty SK, Sarkar JK, Chakravarty MS, Mukherjee MK, Mukherjee KK, Das BC, et al. The first epidemic of Japanese encephalitis studied in India-Virological studies. Indian J Med Res 1975;63:77.

15. Mourya DT, Ilkal MA, Mishra AC, Jacob PG, Pant U, Ramanujam $\mathrm{S}$ et al. Isolation of Japanese encephalitis virus from mosquitoes collected in Karnataka state, India from 1985 to 1987. Trans R Soc Trop Med Hyg. 1989;83:550-552.

16. Pant U, Ilkal MA, Soman RS, Shetty PS, Kanojia PC, Kaul HN. First isolation of Japanese encephalitis virus from the mosquito, Culex tritaeniorhynchus Giles, 1901 (Diptera: Culicidae) in Gorakhpur district, Uttar Pradesh. Indian J Med Res. 1994;99:149-151.

17. Kanojia PC. Ecological study on mosquito vectors of Japanese encephalitis virus in Bellary district, Karnataka. Indian J Med Res 2007;126:152-157.

18. Dhanda V, Kaul HN. Mosquito vectors of Japanese encephalitis virus and their bionomics in India. Proc Indian Natl Sci Acad 1980;46B:759-768.

19. Naik PS, Ilkal MA, Pant U, Kulkarni SM, Dhanda V. Isolation of Japanese encephalitis virus from Culex pseudovishnuiColless 1957 (Diptera: Culicidae) in Goa.
Indian J Med Res 1990;91:331-333.

20. Reuben R. Studies on the mosquitoes of North Arcot district, Madras state, India. Part 3. Host preference for pigs, birds and some small mammals. J Med Entomol 1971;8:258-62.

21. Kaur S. Comparative studies on male genitalia of three species of Culex vishnui subgroup viewed with scanning electron microscope

Entomon.2005;30(3):243-247.

22. Kaur S, Airi M, Tewari PK. Intraspecific variations in three vector species of Culex vishnui(Diptera: Culicidae) based on male genitalia. Entomon. 2010;34(3):123-135.

23. Darsie RF, Pradhan SP. The Mosquitoes of Nepal: their identification, distribution and biology. Mosquito Systematic. 1990;22:66-130.

24. Dandawate CN, Rajagopalan PK, Pavri KM, Work TH. Virus isolations from mosquitoes collected in North Arcot district, Madras state and Chittoor district, Andhra Pradesh between November 1955 and October 1957. Indian J Med Res 1969;57:1420-1426.

25. Soman RS, Kaul HN, Guru PY, Modi GB, Guttikar SN, Dhanda V. A report on the mosquitoes collected during an epidemic of encephalitis in Burdwan and Bankura districts, West Bengal. Indian J Med Res 1976;64:808813.

26. Mahadev PVM, Dhanda V, Geevarghese G, Mishra AC, Deshmukh PK, Kaul HN, et al. Studies on the mosquitoes of Bankura district, West Bengal: Adult populations. Indian J Med Res 1978;68:248-263.

27. Pantawane PB, Dhanze H, Verma MR, Singh G, Kapdi A, Chauhan J, et al. Seasonal occurrence of Japanese encephalitis vectors in Bareilly district, Uttar Pradesh, India. J Vector Borne Dis. 2017;54(3):270-276.

28. Ramesh D, Muniaraj M, Samuel PP, Thenmozhi V, Venkatesh A, Nagaraj J et al. Seasonal abundance \& role of predominant Japanese encephalitis vectors Culex tritaeniorhynchus\&Cx. gelidus Theobald in Cuddalore district, Tamil Nadu. Indian J Med Res. 2015;142:S2329.

29. Philip PS, Ramesh D, Thenmozhi V, Nagaraj J, Muniaraj M, Arunachalam N. Japanese Encephalitis vector abundance and infection frequency in Cuddalore District, Tamil Nadu, India: a five-year longitudinal study. Journal of Entomological and Acarological Research 2016;48(3):5630.

30. Sudeep AB. Culex gelidus: an emerging mosquito vector with potential to transmit multiple virus infections. J Vector Borne Dis 2014;51(4):251-258.

31. Vythilingam I, Oda K, Chew TK, Mahadevan S, Vijayamalar B, Morita K, et al. Isolation of Japanese encephalitis virus from mosquitoes collected in SabakBernam, Selangor, Malaysia in 1992. J Am Mosq Control Assoc 1995;11(1):94-98.

32. Tanaka K, Mizusawa K, Saugstad ES. A revision of the adult and larval mosquitoes of Japan (including the Ryukyu Archipelago and the Ogasawara Islands) and Korea (Diptera: Culicidae). Contrib Am Entomol Inst. 1979;16:1-987.

33. Iyengar M0T. Studies on the epidemiology of filariasis in Travancore, Calcutta. In: Indian Medical Research Memoirs 1938, 30

34. Kanojia PC, Shetty PS, Geevarghese G. A long-term study on vector abundance and seasonal prevalence in 
relation to the occurrence of Japanese encephalitis in Gorakhpur district, Uttar Pradesh. Indian J Med Res. 2003;117:104-110.

35. Reuben R, Thenmozhi V, Philip Samuel P, Gajanana A, Mani TR. Mosquito blood feeding patterns as a factor in the epidemiology of JE in southern India. Am J Trop Med Hyg. 1992;46: 654.

36. Philip Samuel P, Hiriyan J, Thenmozhi V, Balasubramanian A. A note on first isolation of Japanese encephalitis virus from Culex infula Theobald (Diptera,Culicidae). J Com Dis. 1998;30:199. 